\title{
ADAPTASI KOSAKATA BAHASA BALI DALAM BAHASA MELAYU LOLOAN BALI
}

\author{
Anak Agung Putu P., Ni Luh Nyoman Seri M., dan I Nyoman Suparwa \\ Fakultas Sastra Universitas Udayana Bali \\ email: kmserimalini@yahoo.com
}

\begin{abstract}
Abstrak
Penelitian ini bertujuan mendeskripsikan proses dan ranah penyerapan kosakata, kategori kata, dan dinamika fonologi dalam bahasa Melayu Loloan Bali. Metode yang digunakan adalah observasi partisipasi dan data dianalisis dengan teori fonologi generatif. Hasil penelitian sebagai berikut. Pertama, bahasa Melayu Loloan Bali menyerap kosakata bahasa Bali melalui dua proses, yakni adopsi dan adaptasi. Kedua, penyerapan kosakata bahasa Bali ditinjau dari tujuh unsur kebudayaan universal mencakup ranah sistem mata pencaharian, teknologi, sistem pengetahuan, organisasi, dan kesenian. Ketiga, penyerapan kosakata bahasa Bali ditinjau dari perspektif kategori kata terjadi pada kelas kata: (a) nomina, pronomina dan numeralia, (b) verba, dan (c) ajektiva. Keempat, penyerapan kosakata bahasa Bali menyebabkan terjadinya dinamika fonologi dalam bahasa Melayu Loloan.
\end{abstract}

Kata kunci: ranah serapan, kategori kata, dinamika fonologis

\section{ADAPTATION OF BALINESE VOCABULARY IN THE LOLOAN MALAY LANGUAGE IN BALI}

\begin{abstract}
This study aims to describe processes and domains of vocabulary borrowing, word categories, and phonological dynamics in the Loloan Malay language in Bali. The data were collected through participant observations and were analyzed using the generative phonological theory. The results of the study are as follows. First, the Loloan Malay language borrows Balinese vocabulary through two processes, namely adoption and adaptation. Second, the borrowing of Balinese vocabulary in terms of seven universal cultural elements covers the domains of livelihood system, technology, knowledge system, organization, and arts. Third, the borrowing of Balinese vocabulary in terms of word categories occurs in: (a) nouns, pronouns, and numerals; (b) verbs; and (c) adjectives. Fourth, the borrowing of Balinese vocabulary results in the phonological dynamics in the Loloan Malay language.
\end{abstract}

Keywords: borrowing domains, word categories, phonological dynamics

\section{PENDAHULUAN}

Ancaman kepunahan bahasa lokal serta isu pemertahanannya menjadi wacana menarik seiring dengan semakin banyaknya bahasa-bahasa lokal yang tidak lagi digunakan sebagai wahana komunikasi oleh penuturnya. Kepunahan bahasa ditengarai erat kaitannya dengan pergeseran bahasa. Hal ini terjadi manakala guyup tutur suatu bahasa beralih ke bahasa baru secara total sehingga bahasa terdahulu tidak digunakan lagi. Sementara itu, pergerseran bahasa dipengaruhi oleh kedwibahasaan masyarakat (societal 
bilingualism), migrasi, perkembangan ekonomi, sekolah, dan masalah lainnya (Sumarsono, 2009:234).

Apabila dikaitkan dengan isu pergeseran bahasa di atas, bahasa Melayu Loloan Bali merupakan salah satu bahasa minoritas yang sampai saat ini eksistensinya masih dipertahankan oleh penuturnya. Bahasa ini digunakan oleh guyup Loloan yang tinggal di tengahtengah kota Negara. Munculnya komunitas Melayu Loloan dalam bingkai historis tidak dapat dilepaskan dengan kedatangan para ulama Islam yang berasal dari berbagai etnik seperti Makasar/Bugis, Melayu, Jawa, dalam menyebarkan agama Islam di kepulauan nusantara (Parimarta, 2014:168). Guyup ini mulai datang ke Bali pada pertengahan abad ke 17. Mereka adalah pelarian pasukan Gowa, Sulawesi Selatan. Seabad kemudian, pertengahan abad ke-18 muncul gelombang kedua, yakni berasal dari armada angkatan laut dari Pontianak. Mereka inilah yang kemudian menjadi inti guyup Loloan, yang mulai memperoleh konsensi tempat tinggal di di banjar-banjar Loloan. Pertengahan abab ke-19 berdatangan juga pendatang dari Jawa Timur, yang juga beradaptasi ke guyup itu (Sumarsono, 2009:266).

Mengamati lintasan sejarah asal-usul penutur bahasa Melayu Loloan dan membandingkan realitas kebahasaannya saat ini, fakta empiris menunjukkan bahwa bahasa Melayu Loloan masih bertahan. Sebagai bahasa minoritas yang hidup di tengah-tengah bahasa Bali, vitalitas atau daya hidup bahasa ini dapat dikatakan kuat, paling tidak selama tiga abad setelah migrasi penuturnya. Sampai di sini, faktor penyebab pergeseran bahasa akibat migrasi penutur minoritas ke tempat baru yang berimplikasi pada tidak berfungsinya bahasa itu di daerah baru, tidak sepenuhnya relevan. Artinya, khusus dalam bahasa Melayu Loloan, bahasa ini tidak kehilangan seluruh fungsinya setelah dibawa ke tempat baru oleh penu- turnya, seperti halnya yang terjadi pada etnik-etnik imigran di Amerika Serikat. Walaupun demikian, bahasa Melayu Loloan juga tidak dapat terlepas dari pengaruh bahasa Bali dan bahasa Indonesia sebagai bahasa resmi dan pergaulan lintas etnis. Keadaan bahasa tersebut membuat pertumbuhan dan perkembangan bahasa Melayu Loloan Bali berdinamika di bawah pengaruh bahasa Indonesia dan bahasa Bali (Suparwa, 2007:ix).

Dalam dinamika pertumbuhan dan perkembangan bahasa Melayu, bahasa ini dipengaruhi oleh dua daya (kekuatan), yaitu daya sentripetal dan sentrifugal. Daya sentripetal menyebabkan adanya retensi dalam bahasa Melayu Loloan Bali yang juga merupakan akibat sikap resistensi komunitas Loloan terhadap pengaruh bahasa lain (Suparwa, 2007:ix). Hal itu disebabkan, terutama oleh keberadaan bahasa Melayu Loloan sebagai identitas keetnisan dan sebagai lambang komunitas muslim Loloan. Lebih jauh, Sumarsono (2009:266) mengatakan bahwa komunitas ini merupakan penganut islam yang tidak akomodatif terhadap guyup, budaya dan bahasa Bali.

Di sisi lain, daya sentrifugal menyebabkan adanya inovasi dalam bahasa Melayu Loloan dengan penyerapan bahasa Bali sebagai akibat akomodasi pergaulan komunitas muslim Loloan dengan komunitas Bali, terutama dalam pergaulan pendidikan (SD), ekonomi (perdagangan antaretnis), dan sosial budaya serta penyerapan unsur bahasa Indonesia sebagai akibat pergaulan nasional yang bersifat resmi, terutama dalam bidang pendidikan, politik, ekonomi, dan sosial budaya dengan pemakaian bahasa Indonesia. Akomodasi itu terjadi di samping karena faktor situasi sosial (terutama dorongan ekspresif, yaitu keinginan agar diterima oleh mitra wicara) juga karena faktor kebahasaan, yaitu kemudahan ucapan unsur bahasa-bahasa tertentu (Suparwa 2007:ix). 
Berdasarkan fenomena di atas, penyerapan bahasa Bali menimbulkan konsekuensi dinamika sistem fonologi bahasa Melayu Loloan, karena kosakata pada pripsipnya adalah rangkaian bunyi. Penelitian ini akan menelusuri lebih mendalam pengaruh bahasa Bali ke dalam bahasa Melayu Loloan. Titik fokus permasalahan dipilah ke dalam tiga hal, yakni (1) ranah serapan bahasa Bali ke dalam bahasa Melayu Loloan ditinjau dari perspektif tujuh unsur kebudayaan universal; (2) kategori kata bahasa Bali yang diserap ke dalam bahasa Melayu Loloan; dan (3) kaidah perubahan bunyi bahasa Bali setelah diadopsi dan diadaptasi ke dalam bahasa Melayu Loloan.

\section{METODE}

Metode dalam penelitian ini meliputi tiga tahap, yakni tahap (1) penyediaan data, (2) analisis data, (3) penyajian hasil analisis data. Pada tahap penyediaan data digunakan metode cakap dengan teknik dasar pancing dan teknik lanjutan cakap semuka. Data yang diobservasi tidak hanya berupa data lisan, tetapi juga data tulis. Data yang diperoleh diolah dengan menggunakan bantuan speech analyzer dan dianalisis berdasarkan teori Fonologi Generatif(Schane, 1992). Pada tahap akhir, hasil analisis data dapat disajikan dengan metode informal atau berupa deskripsi dengan kata-kata.

\section{HASIL DAN PEMBAHASAN \\ Ranah Serapan Kosa Kata Bahasa Me- layu Loloan dari Bahasa Bali}

Pengaruh bahasa Bali terhadap bahasa Melayu Loloan yang menjadi fokus penelitian ini dilihat dari perspektif leksikon atau kosakatanya. Proses penyerapan kosakata tersebut melalui dua cara, yakni adopsi dan adaptasi. Proses adopsi adalah penyerapan kosakata bahasa Bali secara langsung tanpa perubahan struktur kata. Sementara itu, proses adaptasi merupakan penyerapan kosakata bahasa
Bali dengan perubahan struktur ke dalam bahasa Melayu Loloan.

Proses penyerapan tersebut selanjutnya ditinjau dari tujuh unsur kebudayaan universal yang terdiri atas (1) sistem peralatan hidup, (2) organisasi, (3) kesenian, (4) agama, (5) bahasa, (6) sistem pengetahuan, (7) sistem mata pencaharian (Koentjaraningrat 1980:217-218). Dalam konteks ini, bahasa sebagai media komunikasi tidak dapat dilepaskan dari sistem budaya suatu komunitas.Bahasa merupakan sarana untuk pewarisan kebudayaan karena bahasa merekam seluruh aspek kebudayaan suatu masyarakat itu.

Tidak semua ranah dalam tujuh unsur kebudayaan universal itu menyerap kosakata bahasa Bali secara merata. Dua ranah yang sangat dominan menyerap kosakata bahasa Bali adalah ranah sistem peralatan dan sistem mata pencaharian. Serapan tersebut disajikan dalam bentuk Tabel 1.

Tabel 1. Peralatan Bertani

\begin{tabular}{|c|c|c|c|}
\hline No. & $\begin{array}{c}\text { Bahasa } \\
\text { Bali }\end{array}$ & $\begin{array}{l}\text { Bahasa } \\
\text { Melayu }\end{array}$ & $\begin{array}{c}\text { Arti/ } \\
\text { Padan Kata } \\
\end{array}$ \\
\hline 1. & [lampit] & [lampit] & 'lampit' \\
\hline 2. & [tengala] & [tongala] & $\begin{array}{l}\text { 'sejenis alat untuk } \\
\text { membajak sawah' }\end{array}$ \\
\hline 3. & [ugə] & [ugə] & $\begin{array}{l}\text { 'sejenis alat untuk } \\
\text { membajak sawah' }\end{array}$ \\
\hline
\end{tabular}

Tabel 1 menunjukkan bahwa ranah pertanian menyerap kosakata bahasa Bali. Penyerapan kosakata tersebut disebabkan oleh sampai saat ini tanah-tanah pertanian yang dimiliki oleh penduduk Loloan, sebagian besar dikerjakan oleh masyarakat Bali yang beragama Hindhu yang tinggal di wilayah sekitar Loloan (Informasi Haji Syahdat, diwawancarai 13 September 2014). Inilah yang menyebabkan masyarakat Loloan juga menggunakan leksikon seperti lampit 'garu untuk meratakan tanah dengan ditarik oleh sepasang sapi atau kerbau', uga 'alat yang dipasang pada leher sapi atau kerbau untuk membajak, tenggala 'bajak' (Kamus 
Bahasa Bali-Indonesia, 2008), terutama dalam interaksi dan komunikasi yang terjadi dalam aktivitas pertanian.

Penyerapan kosakata bahasa Bali juga terlihat dalam ranah sistem peralatan kelautan. Hal ini dapat dilihat dalam Tabel 2.

Tabel 2. Peralatan Melaut

\begin{tabular}{lccc}
\hline No. & $\begin{array}{c}\text { Bahasa } \\
\text { Bali }\end{array}$ & $\begin{array}{c}\text { Bahasa } \\
\text { Melayu }\end{array}$ & \multicolumn{1}{c}{$\begin{array}{c}\text { Arti/ } \\
\text { Padan Kata }\end{array}$} \\
\hline 1. & [sau] & [sau] & $\begin{array}{l}\text { 'alat menangkap } \\
\text { ikan tradisonal' }\end{array}$ \\
2. & [dunki] & [dunki] & $\begin{array}{l}\text { 'tempat penyimpanan } \\
\text { ikan tradisional' } \\
\text { 3. pancing yang berkail } \\
\text { banyak' }\end{array}$ \\
\hline
\end{tabular}

Penyerapan kosakata bahasa Bali dalam ranah kelautan disebabkan oleh mata pencaharian masyarakat Loloan yang dahulunya menjadi nelayan. Bahkan, Sumarsono (2009:266) mengatakan bahwa masyarakat Loloan merupakan pelaut dan nelayan yang tangguh, walaupun jumlahnya saat ini sudah semakin sedikit. Namun, kaum tua masyarakat Loloan masih mengenal leksikon-leksikon kelautan tersebut.

Ranah sistem peralatan yang cukup banyak menyerap kosakata bahasa Bali di samping pertanian dan kelautan adalah sistem peralatan dapur. Beberapa contoh leksikon tersebut yang disajikan dalam Tabel 3.

Tabel 3. Peralatan Dapur

\begin{tabular}{|c|c|c|c|}
\hline No. & $\begin{array}{c}\text { Bahasa } \\
\text { Bali }\end{array}$ & $\begin{array}{l}\text { Bahasa } \\
\text { Melayu }\end{array}$ & $\begin{array}{c}\text { Arti/ } \\
\text { Padan Kata }\end{array}$ \\
\hline 1. & [semprong] & [səmpron] & $\begin{array}{l}\text { 'sejenis alat dapur } \\
\text { untuk meniup } \\
\text { supaya api besar/ } \\
\text { sulupan' }\end{array}$ \\
\hline 2. & [kukusan] & [kukusan] & $\begin{array}{l}\text { 'sejenis alat untuk } \\
\text { memasak nasi' }\end{array}$ \\
\hline 3. & [lumor] & [lumor] & 'gelas' \\
\hline 4. & [kəkəb] & [kəkəp] & 'alat penutup nasi' \\
\hline 5. & [səp $t \mathrm{t}]$ & [septt] & 'penjepit' \\
\hline
\end{tabular}

Dalam ranah sistem peralatan dapur, bahasa Melayu Loloan cukup banyak menyerap kosakata bahasa Bali. Umumnya, kosakata ini masih dikuasai oleh generasi tua, sedangkan generasi muda sedikit demi sedikit sudah tidak mengenal kosakata ini, seiring dengan perubahan peralatan dapur yang semakin modern (wawancara dengan Yuyun Maria Ulfa, tanggal 13 September 2014 ).

Ranah berikutnya adalah sistem organisasi dan kesenian. Dalam kedua ranah ini penyerapan kosakata bahasa Bali tidak terlalu banyak ditemukan. Contoh serapan kosakata bahasa Bali dalam bahasa Melayu Loloan pada Tabel 4.

Tabel 4. Ranah Kesenian dan Organisasi

\begin{tabular}{|c|c|c|c|}
\hline No. & $\begin{array}{c}\text { Bahasa } \\
\text { Bali }\end{array}$ & $\begin{array}{l}\text { Bahasa } \\
\text { Melayu }\end{array}$ & $\begin{array}{c}\text { Arti/ } \\
\text { Padan Kata }\end{array}$ \\
\hline 1. & [soka:] & [soka:] & 'kumpulan' \\
\hline 2. & [banjar] & [banjar] & $\begin{array}{l}\text { 'perkumpulan } \\
\text { masyarakat } \\
\text { tradisional Bali' }\end{array}$ \\
\hline 3. & [kandang] & [kəndang] & 'kendang' \\
\hline 4. & [soling] & [soling] & 'seruling' \\
\hline
\end{tabular}

Sedikitnya serapan kosakata bahasa Bali dalam bahasa Melayu Loloan, terutama dalam ranah organisasi dipengaruhi oleh agama Islam yang cenderung tidak akomodatif dalam beberapa ranah dengan bahasa, budaya, dan adat Bali. Organisasi atau kelompok-kelompok masyarakat yang berkembang senada dengan organisasi keislaman, misalnya kelompok mengaji, kelompok pemuda masjid, dan yang lainnya. Begitu pula dalam ranah kesenian, kesenian yang berkembang cenderung berkaitan dengan agama Islam, misalnya kesenian hadrah, zamroh, dan burdah.

Ranah sistem pengetahuan dalam kebudayaan dimaknai sebagai akumulasi perjalanan hidup manusia sebagai makhluk sosial dalam memahami alam sekitar, alam flora dan fauna di tempat tinggal, zat-zat dan benda-benda dalam lingkungannya, tubuh manusia, sifat dan 
tingkah laku manusia, serta ruang dan waktu (Setiadi, 2007:30). Berdasarkan definisi tersebut, ranah sistem pengetahuan juga menyerap kosakata bahasa Bali, seperti terlihat dalam Tabel 5 .

Tabel 5. Ranah Sistem Pengetahuan

\begin{tabular}{|c|c|c|c|}
\hline No. & $\begin{array}{c}\text { Bahasa } \\
\text { Bali }\end{array}$ & $\begin{array}{l}\text { Bahasa } \\
\text { Melayu }\end{array}$ & $\begin{array}{c}\text { Arti/ } \\
\text { Padan Kata }\end{array}$ \\
\hline 1. & [bayle] & [banle] & $\begin{array}{l}\text { 'nama umbi-umbian } \\
\text { sebangsa temu' }\end{array}$ \\
\hline 2. & [isen] & [isen] & 'lengkuas' \\
\hline 3. & [selə] & [sile] & 'ubi' \\
\hline 4. & [cana?] & [cana?] & 'bangau' \\
\hline 5. & [celsn] & [celsn] & 'babi' \\
\hline 6. & [ambu] & [ambu] & 'awan' \\
\hline 7. & [duwəg] & [duwa?] & 'pintar' \\
\hline 8. & [bələr] & [bəlor] & 'nakal' \\
\hline 9. & [buson] & [bosun] & 'janur' \\
\hline 10. & [kupin] & [kopin] & 'telinga' \\
\hline
\end{tabular}

Berdasarkan data di atas, sistem pengetahuan merupakan ranah yang cukup produktif menyerap kosa katabahasa Bali ke dalam bahasa Melayu Loloan. Hal ini menandakan bahwa pengetahuan kebahasaan masyarakat Loloan, terutama terhadap lingkungan alam (physical environment) yang dikodekan dengan bahasa Bali cukup tinggi. Hal ini sekaligus mengindikasikan keeratan interaksi, interelasi, dan interdepedensi masyarakat Loloan dengan lingkungan alamnya.

Ranah terakhir adalah ranah agama. Serapan kosakata bahasa Bali dalam ranah ini ditandai dengan leksikon-leksikon yang bertalian dengan upacara-upacara siklus hidup (life cycle) yang dilakukan oleh masyarakat Loloan. Contoh serapan ranah agama disajikan pada Tabel 6.

Tabel 6. Ranah Agama

\begin{tabular}{|c|c|c|c|}
\hline No. & $\begin{array}{c}\text { Bahasa } \\
\text { Bali }\end{array}$ & $\begin{array}{l}\text { Bahasa } \\
\text { Melayu }\end{array}$ & $\begin{array}{c}\text { Arti/ } \\
\text { Padan Kata }\end{array}$ \\
\hline 1. & $\begin{array}{l}\text { [kapos } \\
\text { punsad] }\end{array}$ & [kapus pusat] & $\begin{array}{l}\text { 'upacara lepasnya } \\
\text { tali pusar' }\end{array}$ \\
\hline 2. & $\begin{array}{l}\text { [lopas } \\
\text { kambut an] }\end{array}$ & $\begin{array}{l}\text { [lopas } \\
\text { kambuwan] }\end{array}$ & $\begin{array}{l}\text { 'upacara saat bayi } \\
\text { berumur } 40 \text { hari' }\end{array}$ \\
\hline 3. & $\begin{array}{l}\text { [monek } \\
\text { trune] }\end{array}$ & $\begin{array}{l}\text { [mone? } \\
\text { trune] }\end{array}$ & $\begin{array}{l}\text { 'upacara pada } \\
\text { saat meningkat } \\
\text { dewasa' }\end{array}$ \\
\hline
\end{tabular}

Dalam ranah agama, hanya sedikit leksikon bahasa Bali yang ditemukan. Saat ini sudah semakin sedikit masyarakat Loloan yang melakukan upacara siklus hidup seperti yang dikodekan dengan bahasa Bali di atas. Kendatipun melakukan upacara tersebut, dari segi sarana upacaranya sudah mengalami penyederhanaan.

\section{Kategori Kata Bahasa Bali yang Diserap ke dalam Bahasa Melayu Loloan}

Kategori kata yang dimaksudkan dalam tulisan ini adalah kelas kata bahasa Bali yang diserap ke dalam bahasa Melayu Loloan. Moelino (1988:78-229) mengelompokkan kelas kata atas (1) nomina, pronominal, dan numeralia (2) verba, (3) adjektiva, (4) adverbial, dan (5) kata tugas. Tidak semua kelas kata bahasa Bali seperti yang disebutkan di atas diserap ke dalam bahasa Melayu Loloan. Kelas kata yang cenderung menyerap kosakata bahasa Bali ke dalam bahasa Melayu Loloan di antaranya adalah kelas kata nomina, pronominal, dan numeralina, verba, dan adjektiva.

Pertama-tama diberikan beberapa contoh serapan kosakata bahasa Bali berkategori nomina yang selanjutnya dipecah lagi menjadi pronomina dan numeralia. Leksikon berkategori nomina adalah kata benda, baik yang terbilang atau yang dapat dihitung (countable) jumlahnya maupun yang tidak dapat dihitung (uncountable). Dalam kategori ini termasuk pula nama-nama diri, kekerabatan, hewan, tumbuhan, pepohonan, peralatan, benda-benda alam, yang secara ekologis digolongkan ke dalam makhluk bernyawa dan tidak bernyawa. Leksikon-leksikon kategori kata nomina yang diserap dari bahasa Bali ke dalam bahasa Melayu Loloan dapat diklasifikasikan ke dalam nomina yang mengacu pada anggota tubuh manusia, sistem pertanian, kelautan, binatang, dan tumbuhan. Contoh serapan bahasa bali berkategori nomina seperti pada Tabel 7. 
Tabel 7. Serapan Bahasa Bali Berkategori Nomina

\begin{tabular}{|c|c|c|c|}
\hline No. & $\begin{array}{c}\text { Bahasa } \\
\text { Bali }\end{array}$ & $\begin{array}{l}\text { Bahasa } \\
\text { Melayu }\end{array}$ & $\begin{array}{c}\text { Arti/ } \\
\text { Padan Kata }\end{array}$ \\
\hline 1. & [gid,at] & [fidat] & 'dahi' \\
\hline 2. & [usu'wan] & [useran] & 'puser' \\
\hline 3. & [kupin] & [kopın] & 'telinga' \\
\hline 4. & [fagut] & [fangot] & 'dagu' \\
\hline 5. & [punsed] & [puset] & 'puser' \\
\hline 6. & [sau] & [sau] & $\begin{array}{l}\text { 'alat menangkap } \\
\text { ikan tradisonal' }\end{array}$ \\
\hline 7. & [selə] & [silə] & ‘ubi' \\
\hline 8. & [cana?] & [cana?] & 'bangau' \\
\hline 9. & [celsn] & [cel\&n] & 'babi' \\
\hline
\end{tabular}

Di samping beberapa contoh kata di atas, masih ada beberapa leksikon lainnya yang diserap ke dalam bahasa Melayu Loloan di antaranya dalam ranah pertanian terdapat kata tenggala 'sejenis alat untuk membajak sawah', uge 'sejenis alat untuk membajak sawah'. Dalam ranah kelautan, misalnya kata dungki' tempat penyimpanan ikan tradisional', rawe 'pancing dengan banyak kail', dan yang lainnya.

Sementara itu, pronomina yang diserap dari bahasa Bali ke dalam bahasa Melayu Loloan tidak terlalu banyak ditemukan. Contoh disajikan Tabel 8.

Tabel 8. Serapan Bahasa Bali Berkategori Pronomina

\begin{tabular}{|c|c|c|c|}
\hline \multirow[b]{2}{*}{ No } & \multicolumn{3}{|c|}{ Pronomina (Istilah Kekerabatan) } \\
\hline & $\begin{array}{l}\text { Bahasa } \\
\text { Melayu }\end{array}$ & $\begin{array}{c}\text { Bahasa } \\
\text { Bali }\end{array}$ & $\begin{array}{c}\text { Arti/ } \\
\text { Padan Kata }\end{array}$ \\
\hline 1. & [pak na] & [pak nənah] & $\begin{array}{l}\text { 'paman yang } \\
\text { merupakan anak } \\
\text { kedua }\end{array}$ \\
\hline 2. & [pak man] & [pak man] & $\begin{array}{l}\text { 'paman yang } \\
\text { merupakan anak } \\
\text { ketiga' }\end{array}$ \\
\hline 3. & [pak tot] & [pak tot] & $\begin{array}{l}\text { 'paman yang } \\
\text { merupakan anak } \\
\text { keempat' }\end{array}$ \\
\hline
\end{tabular}

Leksikon dalam kategori pronomina di atas sampai saat ini masih digunakan dalam secara aktif dalam komunikasi sehari-hari masyararakat Loloan walaupun dalam beberapa hal intensitas penggunaannya sudah mulai tergeser oleh bahasa Indonesia, terutama dengan sebutan om, atau hanya paman saja. Di samping pronomina, diberikan juga contoh serapan kosakata bahasa Bali ke dalam bahasa Melayu Loloan, berkategori numeralia, disajikan pada Tabel 9.

Tabel 9. Serapan Bahasa Bali Berkategori Pronomina

\begin{tabular}{cccc}
\hline & \multicolumn{3}{c}{ Numeralia } \\
\cline { 2 - 4 } No & Bahasa & Bahasa & Arti/ \\
& Melayu & Bali & Padan Kata \\
\hline 1. & [du'v] & [duwo] & 'dua' \\
2. & [selae] & [səlae] & 'dua puluh lima' \\
3. & [sasur] & [sasor] & 'tiga puluh lima' \\
4 & [sekət] & [sekət] & 'lima puluh' \\
\hline
\end{tabular}

Hanya terdapat sedikit kelas kata berkategori numeralia yang diserap dari bahasa Bali ke dalam bahasa Melayu Loloan. Namun, seperti yang ditunjukkan pada Tabel 9, istilah-istilah khusus, seperti selae 'dua puluh lima', sasur 'tiga puluh lima', dan seket 'lima puluh' sampai saat ini masih digunakan, terutama dalam aktivitas perdagangan.

Kategori kata bahasa Bali berikutnya yang cukup banyak diserap ke dalam bahasa Melayu Loloan adalah kategori adjektiva. Kategori adjektiva adalah kategori kata yang ditandai oleh kemungkinannya (1) untuk bergabung dengan partikel tidak, (2) mendampingi nomina, atau (3) didampingi partikel seperti lebih, sangat, agak, (4) mempunyai ciri-ciri morfologis - $i$, misalnya dalam alami, (5) dibentuk menjadi nomina. Berdasarkan batasan tersebut, contoh serapan kosa kata bahasa Bali ke dalam bahasa Melayu Loloan disajikan pada Tabel 10. 
Tabel 10. Serapan Bahasa Bali Beraktegori Adjektiva

\begin{tabular}{|c|c|c|c|}
\hline No & $\begin{array}{l}\text { Bahasa } \\
\text { Melayu }\end{array}$ & $\begin{array}{c}\text { Bahasa } \\
\text { Bali } \\
\end{array}$ & $\begin{array}{c}\text { Arti/ } \\
\text { Padan Kata } \\
\end{array}$ \\
\hline 1. & [duw $\left.\mathrm{or}^{\mathrm{f}}\right]$ & [duw $ə g$ ] & 'pintar' \\
\hline 2. & [onkəp] & [onkəp] & 'panas' \\
\hline 3. & [bobo?] & [bogb॰g] & 'bohon' \\
\hline 4. & [gədə?] & [gəd,əg] & 'kesal' \\
\hline 5. & [bolog] & [bolog] & 'bodoh' \\
\hline 6. & [bonol] & [bonol] & 'tuli' \\
\hline 7. & [kolo?] & [kolok] & 'bisu' \\
\hline 8. & [bod I ?] & [bod, Ik] & 'sodikit' \\
\hline 9. & [oyot] & [uyot] & 'ribut' \\
\hline
\end{tabular}

Di samping beberapa contoh di atas, masih ada beberapa kata lain yang diserap ke dalam bahasa Melayu Loloan, di antaranya kata seken 'serius', aeng 'seram', alus 'halus', anteng 'rajin', katos 'keras', bongol 'tuli'.

Kategori terakhir adalah kelas kata verba. Verba merupakan kata kerja yang secara sintaktik berfungsi sebagai predikat. Sebagian besar verba mewakili kandungan makna tindakan, perbuatan, keadaan, dan proses. Contoh kosakata bahasa Bali berkategori verba yang diserap ke dalam bahasa Melayu Loloan disajikan pada Tabel 11.

Tabel 11. Serapan Bahasa Bali Berkategori Verba

\begin{tabular}{|c|c|c|c|}
\hline No & $\begin{array}{l}\text { Bahasa } \\
\text { Melayu }\end{array}$ & $\begin{array}{c}\text { Bahasa } \\
\text { Bali }\end{array}$ & $\begin{array}{c}\text { Arti/ } \\
\text { Padan Kata }\end{array}$ \\
\hline 1. & [fagor] & [Jagor] & 'jagur' \\
\hline 2. & [kade?] & [kedck] & 'tertawa' \\
\hline 3. & [kələm] & [kələm] & 'tenggelam' \\
\hline 4. & [mont?] & [menti?] & 'tumbuh' \\
\hline 5. & [porai] & [perai] & 'libur' \\
\hline 6. & [bolas] & [bolas] & 'cerai' \\
\hline 7. & [nəmpa $\mathrm{i}]$ & [nəmpahin] & 'memesan' \\
\hline
\end{tabular}

Kategori verba yang diserap dari bahasa Bali ke dalam bahasa Melayu Loloan cukup banyak. Di samping beberapa contoh kata pada Tabel 11, masih ada kosa kata berkategori verba yang diserap ke dalam bahasa Melayu Loloan, di antaranya kata mewaban 'menguap', pegat 'putus', engkeb 'sembunyi', kambang 'mengapung', kenyem 'senyum', uber 'kejar', tengteng 'bawa', uber 'kejar' dan yang lainnya.

\section{Dinamika Fonologi Bahasa Bali yang Diserap Bahasa Melayu Loloan}

Terserapnya bahasa Bali ke dalam bahasa Melayu Loloan dalam berbagai ranah kehidupan masyarakat Loloan seperti yang terlihat dalam kategori katanya, membawa konsekuensi terhadap dinamika bunyi bahasanya. Sebelum membahas dinamika bunyi bahasa Melayu Loloan yang berasal dari bahasa Bali, terlebih dahulu dijelaskan sistem bunyi bahasa tersebut.

\section{Sistem Bunyi Bahasa Melayu Loloan}

Menurut Suparwa (2007), bahasa Melayu Loloan di Bali memiliki enam buah segmen vokal fonemis di antaranya $/ \mathrm{i}, \mathrm{e}, \mathrm{u}$, $\mathrm{o}$, ə, a/. Dalam realisasi fonetisnya, empat segmen vocal, yakni /i, e, u, o/ dapat mengalami pengenduran yang masing-masing menjadi $[1, \varepsilon, \mho, 0]$. Dengan demikian, secara fonetis ditemukan sepuluh bunyi vokal dalam bahasa Melayu Loloan Bali, yaitu [i, e, u, o, ə, a, l, $\varepsilon$, v, o]. Bunyi vokal bahasa Melayu Loloan dan alofonnya dapat dilihat dalam Tabel 12.

Tabel 12. Bunyi Vokal Bahasa Melayu Loloan Bali dengan Alofonnya

\begin{tabular}{cccc}
\hline Posisi & Depan & Tengah & Belakang \\
\cline { 2 - 4 } Lidah & Tidak bulat & Tidak bulat & bulat \\
\hline Tinggi & I & & $u$ \\
& {$[\mathrm{I}]$} & & {$[0]$} \\
Sedang & $\mathrm{E}$ & & 0 \\
& {$[\varepsilon]$} & $\partial$ & {$[0]$} \\
Rendah & & a &
\end{tabular}

Keterangan. [...] : Alofon.

Sementara itu, bunyi konsonan dalam bahasa Melayu Loloan secara fonemis berjumlah delapan belas segmen yakni / $p, b$, t, d, c, j, k, g, s, h, m, n, n, n, l, r, y, dan w/. Delapan belas konsonan tersebut dapat 
Tabel 13. Bunyi Konsonan Bahasa Melayu Loloan Bali dengan Alofonnya

\begin{tabular}{lccccccc}
\hline Cara Artikulasi & \multicolumn{5}{c}{ Tempat Artikulasi } \\
\cline { 2 - 7 } & Bilabial & Alveolar & Palato-Alveolar & Palatal & Velar & Glotal \\
\hline Hambat & TB & P & T & C & $\mathrm{k}$ & {$[?]$} \\
& & {$\left[\mathrm{p}^{>}\right]$} & {$\left[\mathrm{t}^{>}\right]$} & & {$\left[\mathrm{k}^{>}\right]$} & \\
& $\mathrm{B}$ & $\mathrm{B}$ & $\mathrm{D}$ & $\mathrm{J}$ & $\mathrm{g}$ & \\
Frikatif & $\mathrm{TB}$ & & $\mathrm{S}$ & & & $\mathrm{H}$ \\
Nasal & & $\mathrm{M}$ & $\mathrm{N}$ & $\mathrm{n}$ & $\mathrm{n}$ & \\
Lateral & & & $\mathrm{L}$ & & & & \\
Getar/Tril & & & $\mathrm{R}$ & & $\mathrm{y}$ & $\mathrm{w}$ & \\
Semi Vokal & & & & & $\mathrm{y}$ &
\end{tabular}

Keterangan : TB : Tak Bersuara $\quad$ B : Bersuara

diklasifikasikan menjadi (1) bunyi yang tergolong bunyi hambat, di antaranya $/ p$, b, t, d, c, j, k, g/; (2) bunyi frikatif /s/ dan /h/; (3) nasal di antaranya $/ \mathrm{m}, \mathrm{n}, \mathrm{n}, \mathrm{n} /$, (4) bunyi lateral /l/; (5) bunyi tril /r/; dan bunyi yang tergolong semi vokal $/ y /$ dan /w/. Segmen konsonan tersebut disajikan dalam Tabel 13.

Apabila dilihat dari perspektif penuturnya, sebagian besar masyarakat Loloan secara pasif dapat mengerti beberapa percakapanbahasa etnis lain (seperti bahasa Bali dan Jawa). Namun, sebagian besar lagi mengatakan bahwa beberapa bentuk tuturan yang lebih rumit, seperti lelucon dan pepatah dalam bahasa etnis lain tersebut tidak dimengerti. Terlebih jika diminta untuk menuturkannya (bahasa Bali misalnya). Hampir semua informan dalam penelitian ini mengatakan bahwa mereka tetap merasa kaku untuk menggunakan bahasa Bali dan lebih memilih untuk tetap berbahasa Melayu Loloan.

Pemahaman bahasa yang sama antaretnis yang tinggal di wilayah Loloan seringkali menyebabkan terjadinya penggunaan komunikasi dua bahasa yang berbeda antarpenutur. Misalnya, orang Bali tetap menggunakan bahasa Bali pada saat berbicara dengan orang Loloan yang juga menggunakan bahasa Melayu. Kendatipun demikian, komunikasi yang terjalin tetap berjalan lancar. Hal ini terjadi, mi- salnya, dalam ranah perdagangan. Komunikasi ini seringkali terjadi di desa Loloan, terlebih masyarakat Loloan Timur dengan lingkungan penduduk yang heterogen. Desa ini terdiri atas lingkungan Ketugtug, Loloan Timur, dan Merta Sari. Di setiap lingkungan ini terdapat penduduk Bali yang juga menggunakan bahasa Bali dalam komunikasi sehari-harinya (di samping terkadang ikut berbahasa Loloan).

Kegiatan perdagangan, gotong royong, rapat desa, dan silaturahmi menjadi wahana masuknya unsur-unsur serapan bahasa Bali ke dalam bahasa Melayu Loloan. Hal ini barangkali sudah terjadi sejak dahulu, pada masa-masa awal migrasi penutur asli Loloan yang berasal dari Gowa, Pontianak, dan Jawa ke tanah Bali. Pada saat mereka tiba di Bali, bahasa mereka (Melayu) masih tetap dipertahankan. Bahasa Melayu yang digunakan tidak bisa melambangkan gagasan, benda-benda, lingkungan ekologi, aktivitas, karakter, dan peristiwa yang ada di tempat barunya. Hal ini mengharuskan penduduk Loloan menyerap bahasa Bali sebagai bahasa lokal saat itu. Hal ini terbukti dari leksikon-leksikon verba, nomina, adjektiva, pronomina, numeralia yang diserap dari bahasa Bali, seperti tercermin pada pembahasan di atas.

Dinamika sosial budaya dan mobilitas masyarakat Loloan yang semakin tinggi 
saat ini memungkinkan terjadinya perkawinan campur antara masyarakat Loloan dengan warga di luar Loloan. Hal ini misalnya terjadi pada keluarga Nurkholik warga Loloan, yang menikah dengan Ni Komang Yuni Suartami warga Bali yang berasal dari Dauh Waru, Jembrana. Walaupun intensitas penggunaan bahasa Bali dalam perkawinan campur ini tidak terlalu tinggi, Komang Yuni Suartami dalam beberapa hal tetap menggunakan bahasa Bali, terutama terbatas dalam ranah keluarga. Sikap akomodatif warga Loloan dalam beberapa ranah ini menyebabkan bahasa Bali terserap ke dalam bahasa Melayu Loloan. Bahkan, beberapa warga Loloan, tidak menyadari kosakata yang digunakannya berasal dari bahasa Bali.

Proses penyerapan bahasa Bali ini dilakukan melalui dua cara yakni adopsi (diserap secara utuh) dan adaptasi (diserap dengan perubahan bentuk). Proses adopsi yang ditemukan dalam bahasa Melayu Loloan dapat dilihat dalam Tabel 14.

Tabel 14. Proses Adopsi Kosakata Bahasa Bali

\begin{tabular}{|c|c|c|c|}
\hline No. & $\begin{array}{c}\text { Bahasa } \\
\text { Bali }\end{array}$ & $\begin{array}{l}\text { Bahasa } \\
\text { Melayu }\end{array}$ & $\begin{array}{c}\text { Arti/ } \\
\text { Padan Kata }\end{array}$ \\
\hline 1. & [alas] & [alas] & 'hutan' \\
\hline 2. & [ambu] & [ambu] & 'awan' \\
\hline 3. & [balan] & [balan] & 'belalang' \\
\hline 4. & [banle] & [banle] & $\begin{array}{l}\text { 'nama umbi- } \\
\text { umbian' }\end{array}$ \\
\hline 5. & [bəlas] & [bəlas] & 'berpisah' \\
\hline 6. & [bələr] & [bələr] & 'nakal' \\
\hline 7. & [cəmər] & [cəmər] & 'kotor' \\
\hline 8. & [jagor] & [jagor] & 'pukul' \\
\hline 10. & [kacın] & {$[\mathrm{kac} ı \mathrm{n}]$} & 'kelingking' \\
\hline 11. & [wanen] & [wansn] & ‘berani' \\
\hline
\end{tabular}

Kosakata bahasa Bali selain diserap secara utuh, ada juga yang mengalami perubahan struktur (fonologis). Contoh kata-kata yang mengalami perubahan fonologis disajikan dalam Tabel 15.
Tabel 15. Proses Adaptasi Kosakata Bahasa Bali

\begin{tabular}{|c|c|c|c|}
\hline No. & $\begin{array}{c}\text { Bahasa } \\
\text { Bali }\end{array}$ & $\begin{array}{l}\text { Bahasa } \\
\text { Melayu }\end{array}$ & $\begin{array}{c}\text { Arti/ } \\
\text { Padan Kata }\end{array}$ \\
\hline 1. & [bəlig] & [bol I ?] & 'licin' \\
\hline 2. & [gədəg] & [gədə?] & 'marah' \\
\hline 3. & [sowak] & [sowa?] & 'lemah' \\
\hline 4. & [mont I k] & {$[$ mont I ? ] } & 'tumbuh' \\
\hline 5. & [yond Ih] & [yəndsh] & 'menyala' \\
\hline 6. & [subən] & [sobən] & 'giwang' \\
\hline 7. & [busun] & [bosun] & 'janur' \\
\hline 8. & [pipis] & [potis] & 'uang' \\
\hline 9. & [onkәр] & [oykәp] & 'panas' \\
\hline 10. & [punsəd] & [pusət] & 'puser' \\
\hline 11. & [uwad] & [uwat] & 'kendur' \\
\hline 12. & {$\left[\mathrm{u}^{\mathrm{w}} \mathrm{ab}\right]$} & [u $\left.\mathrm{u}^{\mathrm{w}} \mathrm{ap}\right]$ & 'menguap' \\
\hline
\end{tabular}

Pembicaraan mengenai adaptasi fonologis dan kaidahnya dibicarakan secara lebih spesifik dalam pembahasan di bawah ini.

\section{Adaptasi Fonologis Bahasa Bali ke dalam Bahasa Melayu Loloan}

Penyerapan bahasa Bali ke dalam bahasa Melayu Loloan menyebabkan terjadinya perubahan bunyi pada leksikonleksikon bahasa Bali. Perubahan bunyi dari bunyi /g/ (velar, hambat, bersuara) menjadi / $/$ (glotal, hambat, tak bersuara), apabila menempati posisi akhir kata. Misalnya, kata belig [bəlıg] 'licin' dan gedeg [gədəg] 'marah' dalam bahasa Bali menjadi kata belik [bəlı?] 'licin' dan gedek [gədə?] 'marah' dalam bahasa Melayu Loloan. Di samping itu, perubahan bunyi dari bunyi /k/ (velar, hambat, tak bersuara) menjadi [?] (glotal, hambat, tak bersuara), juga terjadi apabila menempati posisi akhir kata. Misalnya, kata sowak [sowak] 'lemah' dan mentik [məntık] 'tumbuh' menjadi kata soak [sowa?] 'lemah' dan mentik [məntı?] 'tumbuh' dalam bahasa Melayu Loloan sehingga kaidah perubahan bunyinya dapat ditulis sebagai berikut. 


$$
\begin{aligned}
& \text { [k,g] } \rightarrow \quad \text { [?]/ } \\
& \left\{\begin{array}{l}
- \text { son } \\
+ \text { bel } \\
- \text { malar }
\end{array}\right\} \quad\left\{\begin{array}{l}
- \text { kon } \\
- \text { bel }
\end{array}\right\}
\end{aligned}
$$

Perubahan bunyi juga terjadi pada bunyi/b/ (bilabial, hambat, tak bersuara) menjadi /p/ (bilabial, hambat, tidak bersuara), apabila menempati posisi akhir kata. Misalnya kata ongkeb [onkəb] 'panas' dan $u a b$ [u'ab] 'menguap' dalam bahasa Bali menjadi ongkep [onkəp] 'panas' dan uap [u'ap] dalam bahasa Melayu Loloan sehingga kaidahnya dapat ditulis seperti berikut ini.

$$
\left\{\begin{array}{l}
{[\mathrm{b}]} \\
\text { - kor } \\
+ \text { ant } \\
+ \text { bers }
\end{array}\right\} \quad\left\{\begin{array}{l}
{[\mathrm{p}] /} \\
\text { - bers }
\end{array}\right\}
$$

Konsonan lainnya yang juga mengalami perubahan bunyi adalah bunyi /d/ (alveolar, hambat, bersuara) menjadi / $t$ / (alveolar, hambat, tak bersuara). Misalnya, kata uad [uwad] 'kendur' dan pungsed [punsəd] 'pusar' dalam bahasa Bali menjadi uwat [uwat] 'kendur' dan puset [pusət] 'pusar' dalam bahasa Melayu Loloan.

$$
\left\{\begin{array}{l}
\text { - son } \\
+ \text { kor } \\
+ \text { bers }
\end{array}\right\} \quad\left\{\begin{array}{l}
{[\mathrm{t}] /} \\
\text { - bers }
\end{array}\right\}
$$

Perubahan bunyi dari bunyi /u/ (tinggi, belakang) menjadi bunyi /o/ sedang belakang. Misalnya, kata kuping [kupın] 'telinga' dan subeng [subəワ] dalam bahasa Bali menjadi koping [kopın] 'telinga' dan sobeng [sobən] 'giwang' dalam bahasa Melayu Loloan.

$$
\begin{gathered}
{[\mathrm{u}]} \\
\left\{\begin{array}{l}
+ \text { sil } \\
+ \text { ting } \\
+ \text { bul }
\end{array}\right\}
\end{gathered} \quad\left\{\begin{array}{l}
\text { - ting } \\
\end{array}\right\}
$$

Perubahan bunyi dari bunyi/i/ (tinggi, depan) menjadi bunyi /e/ (sedang, depan). Misalnya, kata pipis [pipıs] 'uang' dan ngendih [ Bali menjadi pepis [pepıs] 'uang' dan ngen-

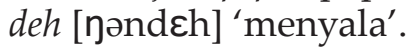

$$
\left\{\begin{array}{l}
+\mathrm{i}] \\
+ \text { sil } \\
+ \text { ting } \\
+ \text { bel }
\end{array}\right\} \quad\left\{\begin{array}{l}
{[\mathrm{e}] / \mathrm{K}-\mathrm{K} \#} \\
\end{array}\right\}
$$

\section{SIMPULAN}

Dalam dinamika pertumbuhan dan perkembangan bahasa Melayu, bahasa ini dipengaruhi oleh dua daya (kekuatan), yaitu daya sentripetal dan sentrifugal. Daya sentripetal menyebabkan adanya retensi dalam bahasa Melayu Loloan Bali yang juga merupakan akibat sikap resistensi komunitas Loloan terhadap pengaruh bahasa lain. Di sisi lain, daya sentrifugal menyebabkan adanya inovasi dalam bahasa Melayu Loloan dengan penyerapan bahasa Bali sebagai akibat akomodasi pergaulan komunitas muslim Loloan dengan komunitas Bali. Pengamatan dan analisis kosakata bahasa Melayu Loloan Bali menunjukkan fakta empiris bahwa bahasa ini juga menyerap kosakata bahasa Bali. Penyerapan dilakukan melalui dua proses, yakni adopsi (penyerapan langsung tanpa perubahan bentuk) dan adaptasi (penyerapan dengan perubahan bentuk, khususnya fonologis).

Ranah-ranah utama penyerapan kosakata bahasa Bali ditinjau dari tujuh unsur kebudayaan universal yang ditemukan, dominan pada ranah (1) sistem mata pencaharian; (2) teknologi; (3) sistem pengetahuan; dan sedikit pada ranah (4) organisasi dan (5) kesenian. Serapan kosakata bahasa Bali ditinjau dari perspektif kategori kata menghasilkan temuan bahwa serapan tersebut cenderung terjadi pada kelas kata (1) nomina, pronomina, numeralia; (2) verba; dan (3) adjektiva. 
Penyerapan kosakata bahasa Bali ke dalam bahasa Melayu Loloan membawa konsekuensi dinamika fonologi bahasa Melayu Loloan. Dinamika fonologi itu terjadi pada bunyi konsonan dan vokal. Pada bunyi vokal terjadi perubahan bunyi dari bunyi /u/ (tinggi, belakang) menjadi bunyi /o/ sedang belakang. Perubahan bunyi dari bunyi /i/ (tinggi, depan) menjadi bunyi /e/ (sedang, depan). Sementara itu, dinamika fonologi pada bunyi konsonan menyebabkan terjadinya perubahan bunyi dari bunyi $/ \mathrm{k}$ / (velar, hambat, tak bersuara) menjadi / / (glotal, hambat, tak bersuara), juga terjadi apabila menempati posisi akhir kata. Perubahan bunyi dari bunyi juga terjadi pad bunyi /b/ (bilabial, hambat, tak bersuara) menjadi /p/ (bilabial, hambat, tidak bersuara), apabila menempati posisi akhir kata. Konsonan lainnya yang juga mengalami perubahan bunyi adalah bunyi /d/ (alveolar, hambat, bersuara) menjadi /t/ (alveolar, hambat, tak bersuara). Di samping itu, terjadi pula perubahan bunyi dari bunyi /g/ (velar, hambat, bersuara) menjadi / / (glotal, hambat, tak bersuara), apabila menempati posisi akhir kata.

\section{UCAPAN TERIMA KASIH}

Ucapan terimakasih diberikan kepada Universitas Udayana yang telah mendanai penelitian ini dan mahasiswa S2 Linguistik yang terlibat dalam penelitian ini. Harapannya, hasil penelitian dapat memperkaya kajian kebahasaan, khususnya kajian bahasa daerah sebagai salah satu antisipasi gejala kepunahan bahasa daerah.

\section{DAFTAR PUSTAKA}

Koentjaraningrat. 1980. Manusia dan Kebudayaan di Indonesia. Jakarta: Penerbit Djambatan.

Pastika, I.W. Fonologi Bahasa Bali Sebuah Pendekatan Generatif Transformasi. Denpasar: Pustaka Larasan.

Parimarta, I.G. 2014. “Karakteteristik Komunitas Melayu Negara Bali Tinjauan Sosial Historis". Majalah Widya Pustaka Jurnal-Jurnal Ilmu Budaya. Denpasar: Fakultas Sastra dan Budaya Universitas Udayana.

Setiadi, M. 2007. Ilmu Sosial dan Budaya Dasar. Bandung: Kencana

Sumarsono. 2009. Sosiolinguistik. Jogjakarta: Sabda.

Suparwa, I.N.. 2007. “Pola Bunyi Bahasa Melayu Loloan Bali:Kajian Leksikal dan Posleksikal". Disertasi. Program Doktor Linguistik Universitas Udayana).

Schane, S.A. 1992. Fonologi Gene-ratif. Terjemahan Gunawan. Jakarta: PT. Gelora Aksara Pratama.

Suryawati, C.I. 2008. Kehidupan Masyarakat Kampung Loloan Masa Kerajaan Jembarana Pada Abad Ke-19.Departemen Kebudayaan dan Pariwisata Balai Pelestarian Sejarah dan Nilai Tradisional Bali, NTB, NTT.

Tim Penyusun. 2008. Kamus Bali-Indonesia Beraksara Latin dan Bali. Denpasar: Dinas Kebudayaan Kota Denpasar. 